УДК 54-16, 67.08

\title{
Study of Composition and Thermal Properties of Ethanollignin Isolated from Aspen-Wood
}

\author{
Victor I. Sharypova, \\ Natalia G. Beregovtsova ${ }^{a}$, Sergei V. Baryshnikova, \\ Angelina V. Miroshnikova ${ }^{a}$ and Boris N. Kuznetsov*a,b \\ ${ }^{a}$ Institute of Chemistry and Chemical Technology SB RAS \\ FRC "Krasnoyarsk Science Center SB RAS" \\ 50/24 Akademgorodok, Krasnoyarsk, 660036, Russia \\ ${ }^{b}$ Siberian Federal University \\ 79 Svobodny, Krasnoyarsk, 660041, Russia
}

Received 11.04.2016, received in revised form 16.06.2016, accepted 20.08.2016

Ethanollignin isolated from aspen wood was characterized by FTIR spectroscopy, elemental and thermogravimetric analysis. IR spectrum of ethanollignin contains adsorption bands characteristic for phenolic structural units of guaiacyl and syringyl types as well as aliphatic fragments and carboxylic groups. According to thermogravimetric data, the thermal decomposition of ethanollignin proceeds in two stages. This is indicated by the appearance on the differential curve on the mass loss the peak of low intensity at $300{ }^{\circ} \mathrm{C}$ and the intensive peak at $390{ }^{\circ} \mathrm{C}$.

The influence of temperature on the conversion of ethanollignin in supercritical ethanol and on the yield and composition of liquid and gaseous products was investigated. The highest conversion of lignin (74 wt. \%) was achieved at temperature $280^{\circ} \mathrm{C}$ as well as the maximum yield of benzene-soluble fraction of liquid products $(42 \mathrm{wt} . \%)$ - at $300^{\circ} \mathrm{C}$.

It was defined by GC-MS that the rise of the temperature of ethanollignin depolymerization in supercritical ethanol from $280{ }^{\circ} \mathrm{C}$ to $300{ }^{\circ} \mathrm{C}$ increases in the obtained liquid products the relative content of methoxyphenols (by 1,6 times) and methoxybenzene (by 2,3).

Keywords: ethanollignin, thermal conversion, supercritical ethanol, liquid products, composition.

DOI: 10.17516/1998-2836-2016-9-3-296-307.

(C) Siberian Federal University. All rights reserved

* Corresponding author E-mail address: inm@icct.ru 


\title{
Изучение состава и термических превращений
}

Этаноллигнина,

\section{выделенного из древесины осины}

\author{
В.И. Шарыпов ${ }^{a}$, Н.Г. Береговцова ${ }^{a}$, \\ С.В. Барышников ${ }^{\text {a }, \text { А.В. Мирошникова }}{ }^{\text {, Б.Н. Кузнецов }}{ }^{\text {a, }}$ \\ " Институт химии и химической технологии СО РАН \\ ФИЦ «Красноярский научный изентр СО РАН» \\ Россия, 660036, Красноярск, Академгородок, 50/24 \\ ${ }^{6}$ Сибирский федеральный университет \\ Россия, 660041, Красноярск, Свободный, 79
}

\begin{abstract}
Методами ИК-спектроскопии, элементного анализа и термогравиметрии охарактеризован этаноллигнин, выделенный из древесины осины. В ИК-спектре этаноллигнина присутствуют полосы поглощения, характерные для фенольных структурных фрагментов гваяцильного и сирингильного типа, алифатических структурных единии, а также карбоксильных групп. Методом термогравиметрии установлено, что термическое разложение этаноллигнина осины протекает в две стадии, которые проявляются на дифференциальной кривой потери массы в виде перегиба при $300{ }^{\circ} \mathrm{C}$ и ярко выраженного пика с максимумом при $390{ }^{\circ} \mathrm{C}$.

Изучено влияние температуры на конверсию этаноллигнина в сверхкритическом этаноле, а также на выход и состав жидких $и$ газообразных продуктов. Наиболее высокая конверсия лигнина (74 мас. \%) достигнута при температуре $280{ }^{\circ} \mathrm{C}$, а максимальный выход бензолрастворимой фракции жидких продуктов (42 мас.\%) - при $300{ }^{\circ} \mathrm{C}$.

Методом хромато-масс-спектрометрии установлено, что увеличение температуры прочесса деполимеризации этаноллигнина в сверхкритическом этаноле с 280 до $300{ }^{\circ} \mathrm{C}$ приводит к росту в образующихся жидких продуктах относительного содержания метоксифенолов (в 1,6 раза) и метоксибензолов (в 2,3 раза).
\end{abstract}

Ключевые слова: этаноллигнин, термическая конверсия, сверхкритический этанол, жидкие продукты, состав.

\section{Введение}

Лигноцеллюлозная биомасса - универсальное возобновляемое сырье для производства биотоплив $[1,2]$. В настоящее время промышленной переработке подвергается только один компонент растительной биомассы - целлюлоза для получения бумаги, эфиров, а также биоэтанола и биобутанола. При этом лигнин является крупнотоннажным отходом, эффективные методы утилизации которого пока отстутствуют.

В ряду разрабатываемых новых технологий - получение востребованных химических веществ, в которых биомасса на начальных стадиях процесса подвергается разделению на основные компоненты - целлюлозу, гемицеллюлозы и лигнин $[1,3-5]$. Полученные из гемицеллюлоз $\mathrm{C}_{5}$-сахара могут быть использованы в качестве субстрата для ферментации или анаэробного 
сбраживания, а также для получения фурфурола, ксилита и других продуктов. Лигнин рассматривается в качестве возобновляемого сырья для получения фенолов и производных бензола.

В литературе описаны различные методы предварительной обработки лигноцеллюлозной биомассы для выделения лигнина [6-8]. Перспективны методы обработки, в которых биомасса подвергается экстракции легкокипящими растворителями при температуре $180-200{ }^{\circ} \mathrm{C}$ либо их смесями с водой с получением так называемых органосольвентных лигнинов [3, 9-12]. В отличие от традиционных технических лигнинов органосольвентные лигнины не содержат серу, затрудняющую их дальнейшую химическую и каталитическую переработку.

Дальнейшую трансформацию лигнинов в вещества с низкой молекулярной массой можно осуществить путем их термохимической конверсии. Эффективным методом деполимеризации органосольвентных лигнинов является терморастворение в среде низших алифатических спиртов в сверхкритических условиях $[13,14]$. Спирты способны алкилировать продукты превращения лигнина, повышая выход жидких биотоплив.

Целью настоящей работы стало изучение состава и термохимических превращений этаноллигнина, выделенного из древесины осины, а также состава жидких и газообразных продуктов конверсии этаноллигнина в сверхкритическом этаноле.

\section{Экспериментальная часть}

Выделение этаноллигнина из древесины осины

Для получения этаноллигнина использовали древесину осины обыкновенной (Populus tremula), содержащую (\% в расчете на массу абсолютно сухой древесины): 46,3 - целлюлозы; 20,4 - лигнина; 24,1 - гемицеллюлоз; 3,6 - водорастворимых веществ; 5,2 - экстрактивных веществ; 0,5 - золы [15]. Воздушно-сухие опилки древесины осины (влажность 5,8 мас. \%) измельчали на вибростенде ВР-2. Для извлечения этаноллигнина по методике [12] отбирали фракцию менее 0,5 мм, содержание которой в измельченной древесине превышало 90 мас. \%. Измельченные опилки высушивали в течение 3 ч при $105^{\circ} \mathrm{C}$.

Навеску высушенных опилок 100 г помещали в реактор автоклавного типа объемом 2 л и добавляли 1000 мл водно-этанольного раствора с концентрацией этанола 60 об. \%. Автоклав герметизировали и продували аргоном для удаления воздуха, затем нагревали до $190{ }^{\circ} \mathrm{C}$ со скоростью $8{ }^{\circ} \mathrm{C} /$ мин и выдерживали при этой температуре в течение 180 мин. После охлаждения до комнатной температуры содержимое автоклава фильтровали на воронке Бюхнера, промывали твердый остаток 60\%-ным водно-этанольным раствором. Полученную после промывки жидкость соединяли с фильтратом и охлаждали до $4{ }^{\circ} \mathrm{C}$. Для выделения лигнина к фильтрату добавляли охлажденную до $4{ }^{\circ} \mathrm{C}$ дистиллированную воду в объемном соотношении 1:3, смесь выдерживали при комнатной температуре 12 ч. Затем лигнин отделяли от раствора фильтрованием и сушили при $50{ }^{\circ} \mathrm{C}$ до постоянной массы. Выход этаноллигнина составил 12,5 мас. \%, что соответствует 56 мас. \% от содержания лигнина Классона в исходной древесине осины.

\section{Исследование состава и термических свойств этаноллигнина}

Элементный состав этаноллигнина определяли с использованием анализатора HCNS-O EA FLASH TM 1112 фирмы «Thermo Quest». ИК-спектроскопические исследования проводили с помощью ИК-Фурье спектрометра Bruker Tensor-27. Образец для анализа готовили в виде та- 
блетки в матрице $\mathrm{KBr}$. Термические свойства лигнина изучали с помощью синхронного термоанализатора STA - 449C Jupiter, совмещенного с масс-спектрометром QMS 403C Aëolos. Использовался платина/платинородиевый держатель (TG-DST сенсор типа S) в сочетании с корундовыми $\left(\mathrm{Al}_{2} \mathrm{O}_{3}\right)$ тиглями с проколотыми крышками. Образец массой $(8,5 \pm 0,2)$ мг подвергался нагреванию от 40 до $800^{\circ} \mathrm{C}$ со скоростью $10^{\circ} \mathrm{C} /$ мин в динамической атмосфере аргона со скоростью потока 40 мл/мин.

Исследование деполимеризации этаноллигнина

в сверхкритическом этаноле

Деполимеризацию лигнина в этаноле проводили во вращающемся автоклаве ёмкостью 0,25 л. В автоклав загружали 3 г лигнина и 30 мл растворителя. Затем его герметично закрывали и продували аргоном для удаления воздуха. Скорость подъема температуры в автоклаве составила $6{ }^{\circ} \mathrm{C} /$ мин. За начало процесса принимали момент достижения заданной температуры $280,300,350$ и $400{ }^{\circ} \mathrm{C}$. Рабочее давление в автоклаве составило 4,0-6,0 МПа.

После охлаждения автоклава газообразные продукты собирали в газометр и определяли их объем. Содержимое автоклава количественно разгружали вымыванием этанолом и переносили на фильтр. Отфильтрованный твёрдый продукт экстрагировали этанолом до тех пор, пока экстрагент не станет прозрачным. По окончании экстракции этанол отгоняли, экстракт доводили до постоянной массы сушкой под вакуумом (1 мм рт. ст.) при комнатной температуре. Выход этанольного экстракта определяли весовым методом после удаления растворителя. Затем этанольный экстракт экстрагировали бензолом. Из бензольного экстракта отбирали аликвоту для исследования ее методом ГЖХ - МС. От экстракта отгоняли растворитель и доводили его до постоянной массы сушкой под вакуумом (1 мм рт. ст.) при комнатной температуре. Выход этанольного и бензольного экстрактов определяли весовым методом после удаления растворителя.

Выход фракции жидких продуктов, не растворимых в бензоле, но растворимых в этаноле, рассчитывали по разности: выход этанольного экстракта - выход бензольного экстракта. Выход твердого остатка определяли весовым методом после его высушивания под вакуумом. Конверсию лигнина в жидкие и газообразные продукты рассчитывали по формуле

$$
\text { конверсия лигнина }=\frac{\text { масса лигнина }(г)-\text { масса твердого остатка }(г)}{\text { органическая масса лигнина(г) }} \times 100 \% .
$$

\section{Исследование продуктов превращения этаноллигнина}

в сверхкритическом этаноле

Газообразные продукты анализировали с помощью хроматографа «Кристалл-2000», снабженного детектором по теплопроводности. Разделение $\mathrm{CO}$ и $\mathrm{CH}_{4}$ осуществляли на набивной колонке длиной $2 \mathrm{~m}$ с цеолитом $\mathrm{NaX}$ в изотермическом режиме при $60{ }^{\circ} \mathrm{C}$. Разделение $\mathrm{CO}_{2}$ и углеводородов проводили на набивной колонке Porapak QP при программировании температуры от 60 до $180^{\circ} \mathrm{C}$ со скоростью подъема температуры $10{ }^{\circ} \mathrm{C} /$ мин.

Аликвотную часть образующихся жидких продуктов анализировали методом хроматомасс-спектрометрии с использованием хроматографа Agilent 7890A, снабженного детектором

$$
-299-
$$


селективных масc Agilent 7000A Triple Quad, при регистрации полного ионного тока. Разделение продуктов осуществляли на капиллярной колонке HP-5MS длиной 30 м с внутренним диаметром 0,25 мм при программировании температуры в интервале $40-250{ }^{\circ} \mathrm{C}$ (скорость увеличения температуры $3{ }^{\circ} \mathrm{C} /$ мин). Идентификацию проводили с использованием базы данных прибора NIST MS Search 2.0.

\section{Результаты и обсуждение}

Состав и термические свойства этаноллигнина древесины лигнина

Элементный состав этаноллигнина, полученного с помощью анализатора HCNS-O EA FLASH, приведен в табл. 1. Выход этаноллигнина составил 56 мас. \% от содержания исходного лигнина в древесине осины. Этаноллигнин осины содержит значительно больше водорода и меньше кислорода, чем уксусно-кислотный, щелочной и серно-кислотный лигнины из древесины осины [16], и сопоставим по элементному составу с органосольвентным лигнином, выделенным из древесины осины экстракцией ацетоном [17].

В ИК-спектре этаноллигнина из древесины осины (рис. 1) присутствуют полосы поглощения, характерные для лигнинов лиственных пород деревьев [18]. Широкая и интенсивная полоса в области $3430 \mathrm{~cm}^{-1}$ указывает на наличие валентных колебаний ОН-групп, вовлеченных в водородную связь. Интенсивные полосы при 2930 и 2852 см$^{-1}$ принадлежат к С-Н-валентным колебаниям в метильных и метиленовых группах соответственно, а интенсивная полоса при $1462 \mathrm{~cm}^{-1}$ - асимметричным деформационным колебаниям в метильных и метиленовых группах. Полоса при $1710 \mathrm{~cm}^{-1}$ характерна для валентных колебаний связей $\mathrm{C}=\mathrm{O}$ в кетонах, карбонилах и сложноэфирных группах; полоса при $1607 \mathrm{~cm}^{-1}-\mathrm{C}-\mathrm{C}-$-валентных колебаний ароматического кольца; при 1515 см$^{-1}-\mathrm{C}-\mathrm{C}$-валентных ароматических скелетных колебаний; при 1424 см$^{-1}$ - C-С-валентных скелетных колебаний ароматического кольца, комбинированных с C-Н-асимметричными плоскостными деформационными колебаниями в метоксильных группах. В ИК-спектре этаноллигнина также присутствуют полосы поглощения, характерные для колебаний сирингильных и гваяцильных фрагментов лигнина (рис. 2) лиственных пород деревьев.

Полосы при 1326 и 1215 см$^{-1}$ можно отнести к скелетным колебаниям сирингильного кольца, полосу при $1115 \mathrm{~cm}^{-1}$ - к плоскостным деформационным колебаниям С-Н-связей сирингильного кольца. О наличии гваяцильных фрагментов в этаноллигнине осины свидетельствуют полосы поглощения при $1270 \mathrm{~cm}^{-1}$, характерные для скелетных колебаний гваяцильного кольца, и полоса при $1031 \mathrm{~cm}^{-1}$, относящаяся к плоскостным деформационным колебаниям гваяцильного кольца. После сопоставления интенсивностей полос поглощения при $1215 \mathrm{~cm}$ (сирингильное кольцо) и при 1031 см$^{-1}$ (гваяцильное кольцо) можно сделать вывод о преоб-

Таблица 1. Элементный состав и зольность этаноллигнина из древесины осины

\begin{tabular}{|c|c|c|c|c|c|c|}
\hline \multirow{2}{*}{ Образец } & \multicolumn{3}{|c|}{ Содержание элементов, мас. \% } & \multicolumn{2}{|c|}{ Атомное отношение } & \multirow{2}{*}{$\begin{array}{c}\text { Зольность, } \\
\text { мас. \% }\end{array}$} \\
\hline & $\mathrm{C}$ & $\mathrm{H}$ & $\mathrm{O}$ & $\mathrm{H} / \mathrm{C}$ & $\mathrm{O} / \mathrm{C}$ & \\
\hline Этаноллигнин & 64,6 & 6,8 & 26,7 & 1,3 & 0,3 & 0,5 \\
\hline
\end{tabular}




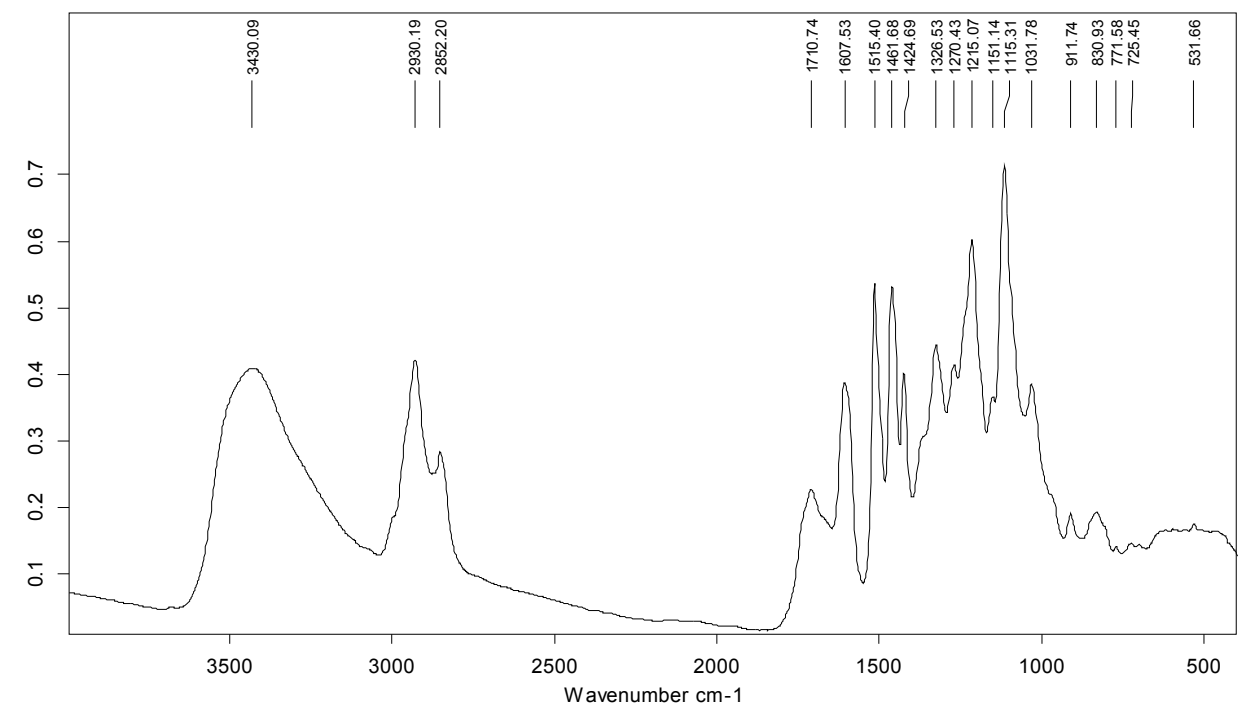

Рис. 1. ИК-спектр этаноллигнина, выделенного из древесины осины<smiles>Cc1ccc(O)cc1</smiles>

Гидроксифенилпропановые

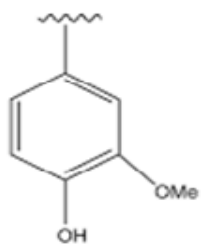

Гваяцилпропановые<smiles>COc1cc(O)c(O)c(OC)c1</smiles>

Сирингилпропановые

Рис. 2. Структурные фрагменты лигнина

ладании в структуре этаноллигнина из древесины осины сирингильных фенилпропановых фрагментов.

Методом термогравиметрии установлено, что термическое разложение этаноллигнина осины протекает в две стадии, которые проявляются на дифференциальной кривой потери массы в виде перегиба при $300{ }^{\circ} \mathrm{C}$ и интенсивного пика с максимумом при $390{ }^{\circ} \mathrm{C}$ (рис. 3). Скорость разложения лигнина в точке максимума кривой потери массы при $390{ }^{\circ} \mathrm{C}$ составляет 4,8 мас. \%/мин.

\section{Термическое превращение этаноллигнина древесины осины}

в среде сверхкритического этанола

Ранее было показано, что конверсия этанола в сверхкритических условиях при температуpax 350 и $400{ }^{\circ} \mathrm{C}$ не превышает соответственно 5 и 12 мас. \% [19].

В процессе термопревращения этаноллигнина в сверхкритическом этаноле температура процесса оказывает существенное влияние на конверсию лигнина, а также на выход и состав жидких, газообразных и твердых продуктов (рис. 4).

$$
-301-
$$




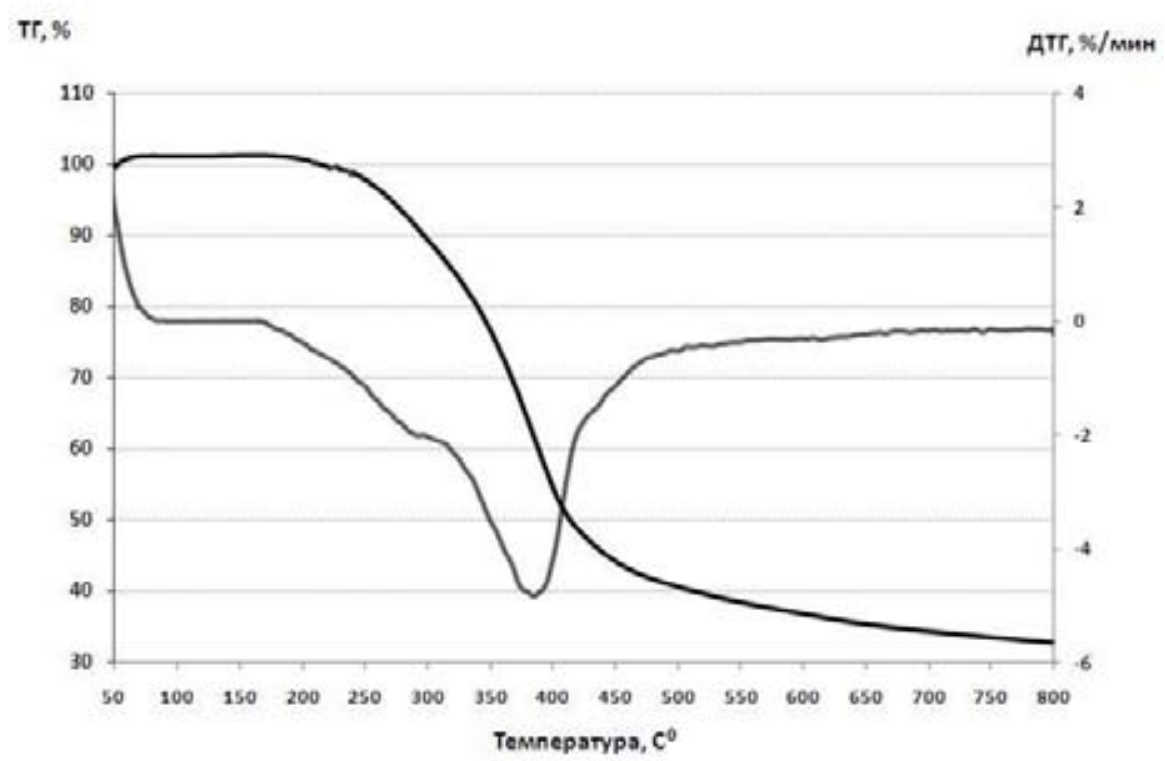

Рис. 3. Интегральная и дифференциальная кривые потери массы этаноллигнина

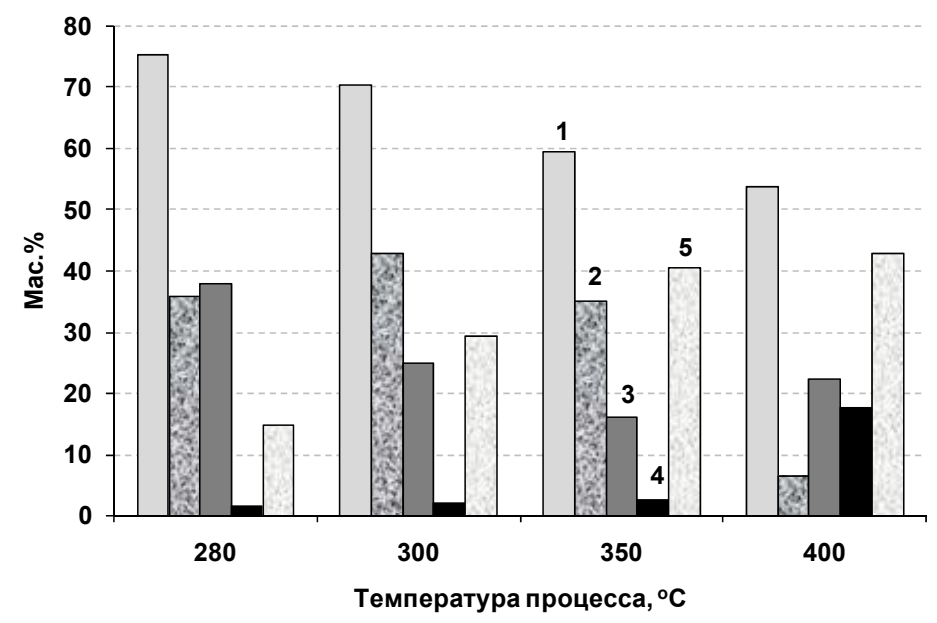

Рис. 4. Влияние температуры процесса деполимеризации этаноллигнина в сверхкритическом этаноле на конверсию (1) и выход бензолрастворимых (2), этанолрастворимых (3), газообразных (4) и твердых (5) продуктов превращения лигнина

Наиболее высокая конверсия лигнина достигнута при температуре $280^{\circ} \mathrm{C}$, максимальный выход бензолрастворимой фракции жидких продуктов - при $300^{\circ} \mathrm{C}$. Увеличение температуры процесса до $400{ }^{\circ} \mathrm{C}$ снижает конверсию этаноллигнина и выход фракций жидких продуктов. Одновременно увеличивается выход газообразных продуктов с 0,8 до 17,5 мас. \% и возрастает выход твердого остатка с 14,7 до 43,0 мас. \%. Полученные данные свидетельствуют о том, что с ростом температуры процесса возрастает вклад вторичных реакций термической деструкции и коксования первичных продуктов деполимеризации этаноллигнина. 
Таблица 2. Влияние температуры процесса на выход газообразных продуктов термопревращения этаноллигнина

\begin{tabular}{|c|c|c|c|c|}
\hline \multirow{2}{*}{ Температура, ${ }^{\circ} \mathrm{C}$} & \multicolumn{4}{|c|}{ Выход газообразных продуктов, мас. \% } \\
\cline { 2 - 5 } & $\mathrm{CO}$ & $\mathrm{CO}_{2}$ & $\mathrm{CH}_{4}$ & остальные углеводородные газы \\
\hline 280 & н.о. $^{*}$ & 0,2 & 0,6 & н.о. \\
\hline 300 & менее 0,1 & 0,3 & 0,8 & менее 0,1 \\
\hline 350 & 0,7 & 1,1 & 1,5 & 0,4 \\
\hline 400 & 6,4 & 3,0 & 4,2 & 3,9 \\
\hline
\end{tabular}

*Не обнаружено.

Выход индивидуальных компонентов газообразных продуктов термопревращения этаноллигнина приведен в табл. 2. Температура процесса оказывает значительное влияние на их состав. При температурах 280 и $300{ }^{\circ} \mathrm{C}$ газообразные продукты состоят из метана и $\mathrm{CO}_{2}$. Увеличение температуры приводит к росту выхода этих компонентов, а также к образованию СО и углеводородных газов, включающих этан, этилен, пропан, пропилен.

Методом ГЖХ-МС в бензолрастворимых продуктах было идентифицировано более 80 индивидуальных соединений, принадлежащих к различным классам органических веществ. В табл. 3 приведены вещества, содержание которых в продуктах превышает 1 отн. \%. Они относятся к типичным продуктам деполимеризации лигнина - производным бензола и фенола, а также содержат преимущественно этиловые эфиры карбоновых кислот. Наличие эфиров в продуктах превращения органосольвентных лигнинов отмечалось в ряде работ [20, 21] и объяснялось протеканием реакций этерификации спиртами продуктов деполимеризации лигнинов.

В составе фенольных продуктов преобладают 2,6-диметоксифенол (сирингол) и 3,5-диметокси-4-гидрокси-фенил-ацетальдегид (рис. 5).

Максимальное их количество обнаружено в жидких продуктах, полученных деполимеризацией лигнина при $300{ }^{\circ} \mathrm{C},-10,7$ и $17,4 \%$ соответственно и при $350{ }^{\circ} \mathrm{C}-11,3$ и $15,0 \%$ соответственно. 2-Метоксифенол (гваякол) образуется в меньших количествах и максимальное его содержание $(3,8 \%)$ обнаружено в жидких продуктах, полученных деполимеризацией этаноллигнина при температуре $350{ }^{\circ} \mathrm{C}$. Метоксибензолы представлены в основном 1,2,4-триметоксибензолом, содержание которого достигает 17,4-17,9 \%.

Групповой состав бензолрастворимых жидких продуктов деполимеризации этаноллигнина в сверхкритическом этаноле приведен в табл. 4. Увеличение температуры процесса термопревращения этаноллигнина с 280 до $300^{\circ} \mathrm{C}$ сопровождается значительным ростом относительного содержания фенолов и метоксибензолов в образующихся бензолрастворимых продуктах. Дальнейшее повышение температуры до $350-400{ }^{\circ} \mathrm{C}$ не приводит к существенному изменению состава жидких продуктов, растворимых в бензоле.

\section{Заключение}

Изучены состав и термические свойства этаноллигнина, выделенного из древесины осины с выходом 56 мас. \% от содержания исходного лигнина. Этаноллигнин сопоставим

$$
-303-
$$


Таблица 3. Вещественный состав продуктов превращения этаноллигнина

\begin{tabular}{|c|c|c|c|c|c|}
\hline \multirow{2}{*}{$\begin{array}{c}\text { Время } \\
\text { выхода, } \\
\text { мин }\end{array}$} & \multicolumn{4}{|c|}{ Содержание, \%* } & \multirow{2}{*}{ Соединение } \\
\hline & $280{ }^{\circ} \mathrm{C}$ & $300^{\circ} \mathrm{C}$ & $350^{\circ} \mathrm{C}$ & $400^{\circ} \mathrm{C}$ & \\
\hline 13,74 & 2,3 & 2,1 & 2,0 & 2,0 & фенол \\
\hline 17,56 & - & 0,1 & 0,2 & 1,2 & 4-метилфенол \\
\hline 17,98 & 0,8 & 2,3 & 3,8 & 3,4 & 2-метоксифенол (гваякол) \\
\hline 19,84 & 0,1 & 0,1 & 0,1 & 1,0 & 2-этилфенол \\
\hline 20,16 & - & - & 0,1 & 1,0 & 2,4-диметилфенол \\
\hline 21,57 & 1,3 & 4,5 & 6,3 & 5,3 & 2-метокси-4-метилфенол \\
\hline 23,68 & - & 0,4 & 0,5 & 4,0 & 3-метокси-1,2-бензолдиол \\
\hline 24,19 & 1,3 & 2,6 & 3,6 & 3,7 & 4-этил-2-метоксифенол \\
\hline 25,42 & сл & 0,2 & 0,3 & 1,7 & 3-метокси-5-метилфенол \\
\hline 26,25 & 3,6 & 10,7 & 11,3 & 9,5 & 2,6-диметоксифенол (сирингол) \\
\hline 26,59 & сл & сл & сл & 4,6 & 3,4-диметоксифенол \\
\hline 26,68 & 1,7 & 4,3 & 4,2 & 3,0 & 2-метокси-4-пропилфенол \\
\hline 28,79 & 7,5 & 17,4 & 17,9 & 14,8 & 1,2,4-триметоксибензол \\
\hline 30,76 & 7,1 & 9,0 & 7,7 & 9,2 & 5-трет-бутилпирогаллол \\
\hline 32,59 & 1,4 & 0,3 & 0,1 & - & 2,6-диметокси-4- (2-пропенил)-фенол \\
\hline 32,76 & 10,4 & 17,4 & 15,0 & 8,6 & $\begin{array}{l}\text { 3,5-диметокси-4-гидроксифенил ацетальдегид } \\
\text { (гомосиреневый альдегид) }\end{array}$ \\
\hline 33,89 & 2,1 & 0,1 & 0,2 & - & 3-метокси-2-нафтол \\
\hline 34,43 & 7,5 & 3,7 & 4,0 & 3,3 & диметиловый эфир декандиовой кислоты \\
\hline 34,79 & 3,4 & - & - & - & 2,6-диметокси-4- (1-пропенил) фенол \\
\hline 35,49 & 1,0 & 1,1 & 0,2 & 0,1 & $\begin{array}{l}\text { 1- (4-гидрокси-3,5-диметоксифенил) -этанон } \\
\text { (ацетосирингон) }\end{array}$ \\
\hline 36,30 & 1,0 & 0,9 & 0,7 & 0,5 & сирингилацетон \\
\hline 37,63 & 1,4 & 0,9 & 0,5 & 0,2 & 3,4,5-триметоксифенилуксусная кислота \\
\hline 40,90 & 11,1 & 4,8 & 4,7 & 4,0 & этиловый эфир гексадекановой кислоты \\
\hline 46,13 & 2,9 & 0,3 & 0,1 & 0,1 & этиловый эфир 9,12-октадекадиеновой кислоты \\
\hline 46,39 & 12,1 & 4,3 & 3,9 & 2,6 & $\begin{array}{l}\text { (9-октадеценовой кислоты (Z) -, этиловый эфир) } \\
\text { этилолеат }\end{array}$ \\
\hline 47,55 & 7,6 & 2,6 & 2,9 & 2,8 & этиловый эфир октадекановой кислоты \\
\hline 55,32 & 2,5 & 2,8 & 2,5 & 1,7 & метиловый эфир дегидроабиетиновой кислоты \\
\hline
\end{tabular}

* \% от суммы площадей всех пиков.

по элементному составу с ацетонлигнином, выделенным из древесины осины, но содержит больше водорода и меньше кислорода, чем уксусно-кислотный, серно-кислотный и щелочной лигнины древесины осины. В ИК-спектре этаноллигнина присутствуют полосы поглощения, характерные для фенилпропановых структурных фрагментов лигнина гваяцильного и сирингильного типов. По данным термогравиметрического анализа термическое разложение этаноллигнина протекает в две стадии, которым соответствуют пики потери массы при 300 
<smiles>COc1cccc(OC)c1O</smiles>

2,6-диметокси-фенол (сирингол)<smiles>COc1cc(C(C)=O)cc(OC)c1O</smiles>

3,5-диметокси-4гидрокси-фенилацетальдегид<smiles>COc1ccccc1O</smiles>

2-метокси-фенол (гваякол)<smiles>COc1ccc(OC)c(OC)c1</smiles>

1,2,4-триметоксибензол

Рис. 5. Структурные формулы преобладающих фенольных продуктов деполимеризации этаноллигнина в сверхкритическом этаноле

Таблица 4. Влияние температуры процесса деполимеризации этаноллигнина в сверхкритическом этаноле на групповой состав бензолрастворимых продуктов (данные ГЖХ-МС)

\begin{tabular}{|l|c|c|c|c|}
\hline \multirow{2}{*}{ Соединения } & \multicolumn{4}{c|}{ Содержание, \%* } \\
\cline { 2 - 5 } & $280{ }^{\circ} \mathrm{C}$ & $300{ }^{\circ} \mathrm{C}$ & $350^{\circ} \mathrm{C}$ & $400^{\circ} \mathrm{C}$ \\
\hline Фенолы, & 37,4 & 55,9 & 56,9 & 58,6 \\
в т.ч. метоксифенолы & 27,9 & 44,7 & 45,9 & 44,2 \\
\hline Сложные эфиры кислот & 43,8 & 18,5 & 18,1 & 14,4 \\
\hline Производные бензола, & 7,5 & 17,8 & 18,4 & 18,8 \\
в т.ч. метоксибензолы & 7,5 & 17,4 & 17,9 & 14,8 \\
\hline
\end{tabular}

* \% от суммы площадей всех пиков.

и $390{ }^{\circ} \mathrm{C}$. Наиболее интенсивная потеря массы со скоростью 4,8 мас. \%/мин происходит при температуре $390^{\circ} \mathrm{C}$.

Установлено, что в процессе термопревращения этаноллигнина в сверхкритическом этаноле температура оказывает существенное влияние на конверсию лигнина, выход и состав жидких и газообразных продуктов. Наиболее высокая конверсия лигнина (74 мас. \%) достигнута при температуре $280^{\circ} \mathrm{C}$, максимальный выход бензолрастворимой фракции жидких продуктов (42 мас. \%) - при температуре $300^{\circ} \mathrm{C}$.

Методом ГЖХ-МС установлено, что увеличение температуры процесса деполимеризации этаноллигнина в среде сверхкритического этанола с 280 до $300{ }^{\circ} \mathrm{C}$ приводит к росту в образующихся жидких продуктах относительного содержания метоксифенолов в 1,6 раза и метоксибензолов в 2,3 раза. Дальнейшее повышение температуры до $400{ }^{\circ} \mathrm{C}$ не вызывает существенного изменения состава продуктов. В составе фенольных продуктов преобладают 2,6диметоксифенол (сирингол) и 3,5-диметокси-4-гидроксифенил ацетальдегид. Максимальное их количество обнаружено в жидких продуктах, полученных деполимеризацией этаноллигнина при $300{ }^{\circ} \mathrm{C}-10,7$ и $17,4 \%$ соответственно - и при $350{ }^{\circ} \mathrm{C}-11,3$ и $15,0 \%$ соответственно. 2-Метоксифенол (гваякол) образуется в меньших количествах, и максимальное его содержание (3,8 \%) выявлено в жидких продуктах, полученных деполимеризацией этаноллигнина при температуре $350{ }^{\circ} \mathrm{C}$. Метоксибензолы представлены в основном 1,2,4-три-метоксибензолом, содержание которого достигает 17,4-17,9 \% при температурах процесса 300 и $350{ }^{\circ} \mathrm{C}$.

$$
-305-
$$


Исследование выполнено за счет гранта Российского научного фонда (проект № 16-1310326).

Этаноллигнин и жидкие продукты его деполимеризации в этаноле изучены с использованием приборов Красноярского регионального центра коллективного пользования СО РАН.

\section{Список литературы}

1. Demirbas A. Progress and recent trends in biofuels. Prog. Energy Combust. 2007. V. 33. № 1. P. 1-18.

2. Huber G. W., Iborra S., Corma A. Synthesis of transportation fuels from biomass: chemistry, catalysts, and engineering. Chem. Rev. 2006. V. 106. P. 4044-4098.

3. Wildschut J., Smit A. T., Reith J. H., Huijgen W. J. J. Ethanol-based organosolv fractionation of wheat straw for the production of lignin and enzymatically digestible cellulose. Bioresource Technology. 2013. V. 135. P. 58-66.

4. Wang H., Tucker M., Ji Y. Recent Development in Chemical Depolymerization of Lignin: A Review. Journal of Applied Chemistry. 2013 (V. 2013). 9 p. https://www. hindawi. com/journals/ jac/2013/838645/

5. Azadi P., Inderwildi O. R., Farnood R., King D. A. Liquid fuels, hydrogen and chemicals from lignin: A critical review. Renewable and Sustainable Energy Reviews. 2013. V. 21. P. 506-523.

6. Kumar P., Barrett D. M., Delwiche M. J., Stroeve P. Methods for pretreatment of lignocellulosic biomass for efficient hydrolysis and biofuel production. Ind. Eng. Chem. Res. 2009. V. 48. № 8. P. 3713-3729.

7. Alvira P., Tomás-Pejó E., Ballesteros M., Negro M. J. Pretreatment technologies for an efficient bioethanol production process based on enzymatic hydrolysis: a review. Bioresour. Technol. 2010. V. 101. P. 4851-4861.

8. Hendriks A. T. W. M., Zeeman G. Pretreatments to enhance the digestibility of lignocellulosic biomass. Bioresour. Technol. 2008. V. 100. № 1. P. 10-18.

9. Kleinert M., Gasson J. R., Barth T. Optimizing solvolysis conditions for integrated depolymerisation and hydrodeoxygenation of lignin to produce liquid biofuel. J. Anal. Appl. Pyrolysis. 2009. V. 85. P. 108-117.

10. Kleinert M., Barth T. Towards a Lignincellulosic Biorefinery: Direct One-Step Conversion of Lignin to Hydrogen-Enriched Biofuel. Energy \& Fuels. 2008. V. 22. P. 1371-1379.

11. Quesada-Medina J., Lopez-Cremades F. J., Olivares-Carrillo P. Organosolv extraction of lignin from hydrolyzed almond shells and application of the d-value theory. Bioresource Technology. V. 101. 2010. P. 8252-8260.

12. Arato C., Kendall Pye E., Gjennestad G. The Lignol Approach to Biorefining of Woody Biomass to Produce Ethanol and Chemicals in Applied Biochemistry and Biotechnology. Humana Press Inc. 2005. V. 121-124.

13. Hu J., Shen D., Wu S., Zhang H., Xiao R. Composition Analysis of Organosolv Lignin and Its Catalytic Solvolysis in Supercritical Alcohol. Energy Fuels. 2014. V. 28. № . 7. P. 4260-4266.

14. Kim J-Y., Park J., Kim U. -J., Choi J. W. Conversion of Lignin to Phenol-Rich Oil Fraction under Supercritical Alcohols in the Presence of Metal Catalysts. Energy \& Fuels. 2015. V. 29. № . 8. P. 5154-5163. 
15. Шарыпов В. И., Береговцова Н. Г., Барышников С. В., Жижаев А. М., Кузнецов Б. Н. Изучение термического превращения механохимически активированной древесины осины в присутствии высококремнеземного цеолита. Журнал Сиб. федер. ун-та. Химия. 2015. Т. 8. №2. C. 190-201. (Sharypov V. I., Beregovtsova N. G., Baryshnikov S. V., Zhyzhaev A. M., Vosmerikov A. V., Kuznetsov B. N. The Study of Thermal Conversion of Mechanically Activated Aspen Wood in the Presence of High-Silica Zeolite Catalyst. J. of Siberian Federal University. Chemistry. 2015. V. 8. № 2. C. 190-201. )

16. Шарыпов В. И., Гришечко Л. И., Тарасова Л. С., Барышников С. В., Кузнецов Б. Н. Исследование термического разложения образцов лигнина, выделенных из древесины осины различными методами. Журнал Сиб. федер. ун-та. Химия. 2011. Т. 3. № 4. С. 221-231. (Sharypov V. I., Grishechko L. V., Tarasova L. S., Baryshnikov S. V., Kuznetsov B. N. Investigation of Thermal Decomposition of Lignin Samples Isolated from Aspen Wood by Various Methods. Journal of Siberian Federal University. Chemistry. 2011. V. 3. №4. Р. 221-231).

17. Шарыпов В. И., Кузнецов Б. Н., Яковлев В. А., Береговцова Н. Г., Барышников С. В., Дьякович Л., Пинель К. Состав жидких продуктов конверсии ацетонлигнина в сверхкритическом бутаноле в присутствии катализаторов $\mathrm{NiCu} / \mathrm{SiO}_{2}$. Журнал Сиб. федер. ун-та. Химия. 2015. T. 8. №3. C. 465-475. (Sharypov V. I., Kuznetsov B. N., Yakovlev V. A., Beregovtsova N. G., Baryshnikov S. V., Djakovitchc L., Pinel C. Composition of Liquid Products of Acetonlignin Conversion Over $\mathrm{NiCu} / \mathrm{SiO}_{2}$ Catalysts in Supercritical Butanol. Journal of Siberian Federal University. Chemistry. 2015. V. 8. №3. P. 465-475. )

18. Базарнова Н. Г., Карпова Е. В., Катраков И. Б. Методы исследования древесины и ее производныхх. Барнаул, Изд-во Алт. гос. ун-та, 2002. 160 с. (Bazarnova N. G., Karpova E. V., Catrackov I. B. Investigation methods of wood and its derivatives. Barnaul: Publishing House of Alt. state. Univ. 2002. 160 c. )

19. Береговцова Н. Г., Шарыпов В. И., Барышников С. В., Гришечко Л. И., Восмериков А. В., Кузнецов Б. Н. Конверсия этанола при 350 и $400{ }^{\circ} \mathrm{C}$ в присутствии цеолитных катализаторов с различным силикатным модулем. Журнал Сиб. федер. ун-та. Химия. 2014. № 2. С. 242-251 (Beregovtsova N. G., Sharypov V. I., Baryshnikov S. V., Grishechko L. I., Vos'merikov A. V., Kuznetsov B. N. Conversion of Ethanol at 350 and $400{ }^{\circ} \mathrm{C}$ in the Presence of Zeolite Catalysts with Different Si/ A1 Ratio. Journal of Siberian Federal University. Chemistry. 2014. V. 7. № 2. P. 242-251. )

20. Ma R., Hao W., Ma X., Tian Y., Li Y. Catalytic Ethanolysis of Kraft Lignin into High-Value Small-Molecular Chemicals over a Nanostructured $\alpha$-Molybdenum Carbide Catalyst. Angew. Chem. Int. Ed. 2014. V. 53. P. $7310-7315$.

21. Cheng S., Wilks C., Yuan Z., Leitch M., Xu C. Hydrothermal degradation of alkali lignin to biophenolic compounds in sub/supercritical ethanol and water-ethanol co-solvent. Polymer Degradation and Stability. 2012. V. 97. P. 839-848. 